\title{
The Effect of Audit Results and Local Characteristics on Financial Performance of Province Governments in Indonesia
}

\author{
Subagyo, Abdul Hadi Sirat, Suwito \\ Research Program of Management, Concentration of Local Financial Management, \\ Khairun University, Ternate
}

\begin{abstract}
This research aim is to analyze the effect of BPK audit results (BPK audit opinion, audit findings and Audit Results Follow-up) and Local Characteristics (Legislative Size, Local Government Size, Local Dependence, and Local Expenditures) on financial performance of provincial government in Indonesia. This research uses secondary data. The research object is the provincial government in Indonesia which has financial statements and audit reports from 2015 to 2019. The research samples are 165 Local Government Financial Reports for 33 Provinces in Indonesia for 2015-2019. The data is analyzed by multiple regression analysis. The research show results that Audit Opinion, Audit Findings, TLHP, Local Government Size, Legislative Size, Local Dependence and Local Expenditure partially have significant on Financial Performance.
\end{abstract}

Keywords: BPK Audit Opinion, Local Characteristics, Financial Performance

DOI: $10.7176 /$ RJFA/12-14-06

Publication date:July $31^{\text {st }} 2021$

\section{INTRODUCTION}

The government and public organizations have big challenges with local autonomy policy. The objectives of decentralization and local autonomy policies are to bring the government closer to its people and improving the quality of public services. The consequence of autonomy implementation is the regions must be able to develop local autonomy in a broad, real, and responsible manner in context of community empowerment, as well as all community potential within unitary state of Republic of Indonesia. On other hand, most striking phenomenon of local autonomy implementation is the high dependence of local governments on central government. This dependence can be seen clearly from financial aspect that local governments lose local discretion to make important decisions, and there is high central government interference with local governments. Local development is quite rapid but the local fiscal dependence to center is higher growing.

Local financial data provides a statistical figure of budget developments and realization, both revenues and expenditures. An evaluation is needed to local financial management and local financial financing. Performance measurement is very important to assess the accountability of local governments in managing local finances. The Corruption Eradication Commission (KPK) has revealed that many governors, deputy governors, mayors, regents, and deputy regents have been entangled in corruption cases ( Rini, 2016).

The Supreme Audit Agency (BPK) is a financial audit institution of Republic of Indonesia. All BPK RI inspections are done in order to encourage the realization of transparency and accountability of state finances. State financial management is not enough without unqualified opinion from BPK. Ideally, efforts to achieve unqualified opinion are also accompanied by efforts to achieve the best performance; there is no corruption and better welfare (Rini, 2016).

BPK does financial statements audit to local governments based on standards. The outputs which are summarized in Audit Results are published 2 times a year. In context of transparency and accountability in implementation of its main duties, functions and authorities (Mulyadi, 2014), BPK is obliged to publish the results of its implementation consistent with provisions of laws and regulations through various media, both conventional and online.

The Supreme Audit Agency (BPK) is based on Law of Republic of Indonesia No. 15 of 2004 on the Audit of State Finance Management and Responsibility. The types of opinions given are unqualified, qualified with exceptions, unreasonable, not expressing an opinion. Audit opinion can become a pressure for local governments in implementation of good governance to produce optimal performance (Nandhya Marfiana, 2018).

Several previous studies have revealed that audit opinion has an effect on financial performance, this is consistent Parwanto \& Harto (2017) and Nur Ade Noviyanti (2017) that betters the BPK audit opinion obtained by district/city shows better the performance in management of local finances. However, other research states that audit opinion does not affect the financial local government performances. Local governments have not paid much attention to results of audit opinions to improve the financial performance of their local governments (Darmawan, 2019).

In addition to audit opinion, there are other audit findings. The audit findings contain weaknesses in internal control, fraud, irregularities, or non-compliance with laws and regulations. The audit findings become benchmark in assessing the financial local government performance (Sudarsana \& Rahardjo, 2013). 
Mustikarini, Widya Astuti, Dan Fitriasari (2012) showed that more and more audit findings indicate that financial management of local government is not good, so it affects financial performance. The more reasonable the financial statements show higher the level of opinion on financial statements. This is consistent with Article 16 paragraph 1 of Law Number 15 of 2004 on State Financial Management and Responsibility.

One variable to effect audit opinion is audit findings. Siregar and Rudiansyah (2019), Widodo and Sudarno (2017), Sari et al (2015), and Zahara and Malichah (2017) found that that audit findings have an effect on audit opinion. There are two types of audit findings, namely internal control systems and non-compliance with laws and regulations. This research will discuss the two audit findings.

The follow-up inspection variable (TLHP) is one focuses of local head. Each local head or organizational leader is required to respond 90 days to BPK findings, so that possibility of audit opinion for following year is affected by TLHP. Parwanto and Harto (2016) explained relationship of TLHP to performance, and Tresnawati and Apandi (2016) to quality of financial reports.

Research on local characteristics was conducted by Sumarjo (2010) on local government of Pennsylvania ( Patrick, 2010). Suhardjanto, Rusmin, Mandasari, and Brown (2010) examined the effect of local government characteristics on mandatory disclosure consistent with SAP, using the same model as Patrick (2007). Sumarjo (2010) uses the organizational structure and external environment in explaining the characteristics of local government where the organizational structure is proxied by local size, wealth, functional differentiation, age , and educational background of local heads while the external environment is proxied by municipal debt financing and intergovernmental revenue.

This research is very important to increase knowledge about the financial local government performances and government accountants. Furthermore, researchers would like to reveal that performance measurement is a method that can be used by local governments to achieve their goals. Based on description above, this research aims to examine the Effect of Examination Results and Local Characteristics on Financial Performance of Provincial Governments in Indonesia.

\section{LITERATURE REVIEW}

\section{Agency Theory}

The main theory underlying the research on effect of local government characteristics and BPK audit findings on local government performance is explained through the perspective of agency theory. Jensen and Meckling (1976) describe it as a working relationship between the owner (principal) and management (agent). The existence of separation of ownership by principal and control by agents in an organization tends to cause agency conflicts between principals and agents. Basically, public sector organizations are built on basis of agency theory (Halim and Abullah, 2005). Lane (2000) agency theory can be applied in public organizations.

Agency Theory stated that management of local governments must be monitored to ensure that management is done based on various applicable rules and regulations. Law No. 15 of 2004 (Law No. 15/2004 ) stated that Examination is a process of problem identification, analysis, and evaluation done independently, objectively, and professionally based on examination standards, to assess the truth, accuracy, credibility, and reliability of information regarding the management and responsibility of state finances. The higher accountability of local governments will improve the balance information received by public to reduce information asymmetry (Setiawan, 2012).

\section{Local Government Agency Report (LPPD)}

PP No. 3 of 2007 stated that LPPD is a report on implementation of local government for one fiscal year based on local development work plan (RKPD) submitted by local head to Government. Law No. 32 of 2004 stated that Government of Local Head must provide a report on LPPD to central government. LPPD scope includes decentralization affairs, co-administration tasks and general government duties. Decentralization affairs include mandatory and optional affairs. Mandatory affairs are very basic matters relating to rights and basic services of citizens. Meanwhile, elective matters are affairs that actually exist in region and have the potential to improve the community welfare, consistent with conditions, characteristics and potential of region superiority.

\section{Performance Evaluation of Local Government Agency (EKPPD)}

Performance is a shown achievement (Big Indonesian Dictionary, 2001). Robbins (1994) stated that performance is a measure of work results based on mutually agreed criteria. Performance measurement is a process of continuous monitoring and reporting achievement of activities, especially progress towards the planned goal (Westin, 1998, in Sumarjo, 2010).

Large attention to performance measurement is caused by opinion that performance measurement can increase efficiency, effectiveness, savings and productivity in public sector organizations (Halachmi, 2005). Article 5 Permendagri No.73/2009 stated that LPPD is used as the main source of information is focused on information on performance achievements at level of policy makers and policy implementers using Key 
Performance Indicators (IKK). Mardiasmo (2002) stated that Key Performance Indicators is a set of indicators that can be considered as a key performance measure of business units, both financial and non-financial.

The results of EKPPD are reports on performance ranking evaluation of local government administration issued by Domestic Ministry. Article 32 of Domestic Minister and Regulation No. 73/2009 stated that performance ranking of provincial and district/city government administrations nationally is based on rank, score and status. Based on this, a Performance Score is obtained for each provincial and district/city government in Indonesia.

\section{BPK Audit Findings}

Audit is an examination process done systematically to find the actual implementation (Pramono, 2008). Hall (2007) stated that audit is a form of independent evidence conducted by expert auditors who express an opinion regarding the fairness of financial statements. Public confidence in reliability of internal financial statements depends directly on validation by independent expert auditors. Audits are done by internal and external auditors. External auditors represent the various interests of third party stakeholders in company, such as shareholders, creditors and government agencies (Hall, 2007).

Law No. 15 of 2004 (Law No. 15/2004) on Audit of State Finance Management and Responsibility stated that Audit is a process of problem identification, analysis, and evaluation done independently, objectively, and professionally based on audit standards, to assess the truth, accuracy, credibility, and reliability of information regarding the management and responsibility of state finances. State financial audits are done by Supreme Audit Agency (BPK) and consist of financial audits, performance audits and audits with specific objectives. The results of examination are opinions, findings, conclusions or recommendations.

\section{Characteristics of Local Government}

Big Indonesian Dictionary stated that characteristic is special feature. Characteristic refers to a person's character, lifestyle and values that develop regularly so that behavior becomes more consistent and easy to notice (Nanda, 2013). The elements contained in a financial report of local government can describe the characteristics of the local government (Lesmana, 2010). The characteristics of local government in this research are reflected in characteristic dimensions below.

\section{a. Local Government Size}

The local government size is a variable that can be measured by total assets, number of employees, total income and productivity levels (Damanpour, 1991). The local government size shows the magnitude of local government. Larger assets, employees and productivity should have better financial performance (Patrick, 2007) in Lesmana (2010). This research uses total assets of local government as a benchmark in determining the local government size.

\section{b. Legislative Size}

The Local Representative Council (DPRD) or members of legislature has duty to oversee the local governments in allocating the budgets rightly. The large DPRD should increase the supervision of local governments to increase the performance (Sumarjo, 2001 ).

DPRD is local people's representative institution in Indonesia who are elected based on results of general election (Wikipedia.com, 2009). Local government structure put DPRD in three administrative areas, namely at provincial level called the Provincial DPRD domiciled in Provincial Capital, district level is called the District DPRD, and City level is called the City DPRD, domiciled in City.

\section{c. Level of Local Dependence}

Regions Financial Dependence level indicates the local finance dependence in development activities through the assistance of central government transfer receipts, as measured by ratio between revenue transfers from Central Government and total Local Budget (APBD). Halim (2007: 5) explained that ratio of local financial dependence is indicated by amount of Transfer Revenue compared to Local Income originating from other sources ( Local Income ). Higher the ratio of local financial dependence means that level of local dependence on external assistance is higher.

\section{d. Local Expenditure}

Regulation of Domestic Minister Number 13 of 2006 on Guidelines for Local Financial Management is amended by Permendagri Number 59 of 2007 and second amendment by Regulation of Domestic Minister Number 21 of 2011 on the second amendment. Local expenditure is defined as the obligation of local government which is recognized as a deduction from net worth". Capital expenditures are used to finance investment activities (add assets) aimed at improving public facilities and infrastructure which can be used directly by community. This type of capital expenditure consists of land, capital and bridges, irrigation, installation capital, network capital , building capital for community activities, monument capital, weapons and security equipment capital expenditures (Ardhini , 2011). 


\section{Conceptual Framework}

This research aim is to analyze the effect of BPK audit results (Audit Opinion, Audit Findings and Follow-up on Audit Results Recommendations) and Local Characteristics (Legislative Size, Local Government Size, Dependence Level, and Local Expenditures) on financial performance of provincial government in Indonesia. Provincial government finances throughout Indonesia. This research refers to research conducted by Endri Parwanto (2017) and Yuni Abdillah (2016). Figure 1 shows a conceptual framework related to research model and relationship between variables

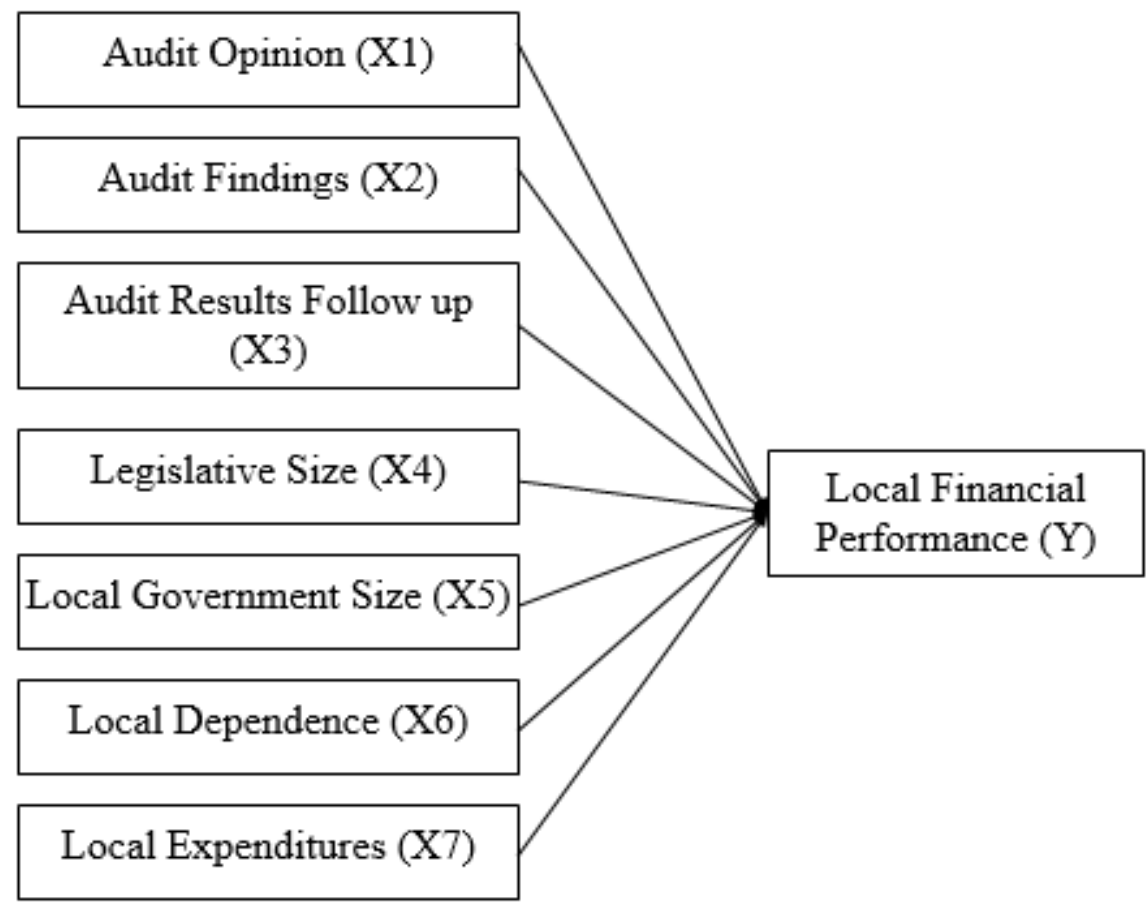

Source: Processed from various references

Figure 1. Conceptual Framework

\section{Hypothesis Development}

Agency theory states that there will be a conflict of interest between the agent and principal. Consistent with Law Number 15 of 2004 on Audit of State Management and Responsibility, State as the principal appoints the BPK to examine the accountability report. Therefore, results of BPK examination, namely the audit opinion, are very important for public as a measuring tool for assessing the performance of state financial management.

Audit Opinion is used as a performance measurement of local financial management. Gita Maiyora (2016) found that audit opinion has a positive effect on local government performance. Marfiana (2013) also showed a relationship between BPK audit opinions on local government financial performance. Based on above explanation, hypothesis $\mathrm{H} 1$ is presented below.

H1 : BPK audit opinion has a positive effect on local government financial performance.

Madiasmo (2009) stated that one agency problem is information asymmetry. The asymmetry in local government financial reports can be traced from BPK audit results listed in audit findings. BPK Regulation Number 1 of 2007 on Standards for State Financial Audit states that audit findings shows internal control weaknesses, fraud, irregularities or non-compliance with provisions of laws and regulations that have the potential to harm state finances. Therefore, audit findings from BPK can be used as a benchmark for local government financial performance.

Mustikarini and Fitriasasi (2012) found that audit findings negatively affect performance of District Government / Municipalities in Indonesia. A similar result was also generated by Sudarsana (2013). It shows more findings on local governments illustrate the lower performance. Based on above explanation, hypothesis $\mathrm{H} 2$ is presented below.

H2 : BPK audit findings have a negative effect on local government financial performance

The Audit Results Follow up from previous period examination, as measured by increasing number of recommendations made by government, should provide higher quality of financial reports represented at a higher level of disclosure, to improve financial performance of local governments.

Pratiwi and Ayani (2016) found that Audit Results Follow up had no effect on Financial Performance. 
Adversely, Sari et al (2015) and Agusti (2014) found that Audit Results Follow up had a positive effect on Financial Performance. Sari et al (2015), stated that more Audit Results Follow up will improve the financial management done by local government so that opinions obtained in next period would be better. Based on above explanation, hypothesis $\mathrm{H} 3$ is presented below.

H3: Follow-up on Audit Results has a positive effect on Local Government Financial Performance.

The local government as agent has the main goal to implement the work program, namely providing the best service for community as a trustee (Artha, et al. , 2015). The government provides good services to community supported by large assets. Masdiantini and Erawati (2016) stated that large local government size will facilitate the implementation of government activities and programs in providing adequate public services. This is confirmed in research of Lin et al., (2010), and Kusumawardani (2012) which show that local government size as measured by total assets has an effect on local government performance. Larger local government size will improve the financial local government performance. Based on above explanation, hypothesis H4 is presented below.

H4: The local government size has an effect on local financial performance.

Kusumawardani (2012) in his research states that logically higher level of supervision will increase the level of responsibility and willingness to work. This level of willingness to work will affect the results that show the local government performance. Sumarjo (2010) stated that Local House of Representatives has task to increase the local governments supervision. It will impact to increase the local government performances, that larger the legislative members will increase the local government performances or vice versa. Based on above explanation, hypothesis $\mathrm{H} 5$ is presented below.

H5: Legislative size has a positive effect on local government financial performance.

Halim (2007: 5) stated that local financial dependence is indicated by amount of Transfer Revenue compared to Local Income from other sources. Julitawati et al (2012) found that matching grant had a negative effect on financial performance of District/City Government. Fontanella and Rossieta (2014) also found that dependence on Central Government has a negative effect on financial reporting accountability. In addition, Wahyuningsih (2016) also found that matching grant have a negative effect on financial performances of local government in Central Java Province. Based on above explanation, hypothesis H6 is presented below.

H6: The local dependence has an effect on financial local government performances.

Law of Republic of Indonesia Number 32 Article 167 paragraph 1 year 2004 states that local expenditures are used to protect and improve the quality of people lives manifested in compulsory affairs services and other services in fields of education, health, provision of social facilities, public facilities, and development of a social security system. Mustikarini, and Fitriasari (2012) showed that a significant relationship between local expenditure and local government performance. Based on above explanation, hypothesis $\mathrm{H} 7$ is presented below. H7: Local expenditure has a positive effect on financial local government performances.

\section{RESEARCH METHODS}

This research examines the hypothesis (Hypothesis testing). Sekaran (2011) explained that hypothesis testing should explain nature of certain relationships, understand differences between groups or the independence of two or more variables. This research examines provincial governments throughout Indonesia which have financial report data and audit reports from 2015 to 2019. This research was conducted over a period of 3 months, namely December 2020 to February 2021.

This research uses secondary data (Sekaran, 2016 from BPK Audit Results Report on Financial Statements of Provincial Governments throughout Indonesia. The data is downloaded from official website of BPK of Republic of Indonesia and other supporting data. The data period taken is from 2015-2019.

Methods of data analysis used in this research is statistic descriptive, test the assumptions of classical and multiple regression analysis. The multiple regression equation used is as follows:

$$
\mathrm{Y}={ }_{0}+{ }_{1} \mathrm{X}_{1}+{ }_{2} \mathrm{X}_{2}+{ }_{3} \mathrm{X}_{3}+{ }_{4} \mathrm{X}_{4}+{ }_{5} \mathrm{X}_{5}+{ }_{6} \mathrm{X}_{6}+{ }_{7} \mathrm{X}_{7}+\mathrm{e}
$$

Where:

$\mathbf{Y}=$ Financial Performance

$\mathbf{X}_{\mathbf{1}}=$ BPK audit opinion

$\mathbf{X}_{2}=$ audit findings

$\mathbf{X}_{\mathbf{3}}=$ Audit Results Follow up

$\mathbf{X}_{4}=$ Legislative Size

$\mathbf{X}_{5}=$ Local Government Size

$\mathbf{X}_{6}=$ Local Dependence

$\mathbf{X}_{7}=$ Local Expenditures

$\beta_{0}=$ Constant 
$\beta_{1}=$ Regression coefficient of BPK audit opinion

$\beta_{2}=$ Regression coefficient of audit findings

$\beta_{3}=$ Regression coefficient of Audit Results Follow up

$\beta_{4}=$ Regression coefficient of Legislative Size

$\beta_{5}=$ Regression coefficient of Local Government Size

$\beta_{6}=$ Regression coefficient of Local Dependence

$\beta_{7}=$ Regression coefficient of Local Expenditures

$\mathrm{e}=$ Standard Error.

\section{RESEARCH RESULTS AND DISCUSSION \\ Descriptive statistics}

The results of frequency analysis show that $18(10.9 \%)$ provincial governments have non-unqualified opinion or while the area with unqualified opinion is 147 (89.1\% ) in 2015-2019 period. Audit findings have an average value of 1.683 with a standard deviation of 4.076 while the minimum value is 0 as in Bali, West Java, Central Java, Riau Islands and Southeast Sulawesi while the maximum value is 1.515, 196.711, 709.33, namely in South Sumatra in 2016. Audit Result Follow-up has average value of 0.693 with a standard deviation of 0.130 while the lowest value was 0.28 or $28 \%$ in Papua provincial government 2018 and highest value was 0.97 or $97 \%$ for Bali province 2019.

\section{Classic assumption test}

The normality test examines the regression model for the confounding or residual variables. The test results show that Kolmogorov Smirnov test on residual value produces a significance value of $0.071>0.05$, based on these results, it is concluded that residuals of regression model are normally distributed, thus the assumption of residual normality has been met.

Ghozali (2013) explained that multicollinearity test examines the correlation between the independent variables. A good regression model should not have a correlation between the independent variables. Multicoloniarity can be seen from value of tolerance and opposite value of Variance Inflation Factor (VIF). The results of multicollinearity test shows tolerance value above 0.1 and VIF value below 10 . It means that there is no high correlation between the independent variables.

Test heteroscedasticity test examines inequality variance of observations residuals to others. The residual variance is called homoscedasticity (Ghozali, 2013). The test results show that significance value of all variables is above 0.05 , it means that there is no heteroscedasticity.

The autocorrelation test examines the correlation between the confounding error in period $t$ and period $t-1$. A good regression model is free from autocorrelation. The test results show that the DW value is 2.149 , with the independent variable $(\mathrm{k}=7)$ and the sample in the study is $165(\mathrm{n}=165)$, using a significance level of $5 \%$. It can be seen in the DW table value is 1.821 . The value $(\mathrm{du} \leqslant \mathrm{dw} \leqslant 4-\mathrm{du})$ obtained is $(1.821 \leqslant 2.123 \leqslant 2.179)$. It can be concluded that there is no positive or negative autocorrelation.

\section{Multiple regression Analysis}

Multiple regression analysis aims to examine the effect of independent variables on dependent variables using SPSS Version 26. Table 1 shows the research results.

Table 1. Regression Test Results

\begin{tabular}{|l|c|c|c|c|c|}
\hline \multicolumn{1}{|c|}{ Variable } & $\begin{array}{c}\text { Unstandardized } \\
(\mathbf{B})\end{array}$ & $\begin{array}{c}\text { Standardized } \\
\text { (Beta) }\end{array}$ & $\begin{array}{c}\text { Std. } \\
\text { Error }\end{array}$ & t count & Sig. \\
\hline BPK audit opinion & 0.096 & 0.114 & 0.045 & 2.157 & 0.033 \\
\hline Audit findings & -0.007 & -0.130 & 0.003 & $-1,980$ & 0.049 \\
\hline Audit Results Follow up & 0.241 & 0.150 & 0.101 & 2,379 & 0.019 \\
\hline Legislative Size & 0.005 & 0.213 & 0.002 & 2,706 & 0.008 \\
\hline Local Government Size & 0.002 & 0.182 & 0.001 & 2.138 & 0.034 \\
\hline Local Dependence & -0.205 & -0.182 & 0.079 & -2.573 & 0.011 \\
\hline Local Expenditures & 0.000 & 0.282 & 0.000 & 4.640 & 0.000 \\
\hline Constant & 0.073 & \multicolumn{5}{|l}{} \\
\hline Fcount;Sig & $19.910 ; 0.000$ & & & & \\
\hline Rsquare & 0.470 &
\end{tabular}

Source: Data processing results, 2021

Table 1 shows that Fcount value is 19.910 and significance is 0.000 . The $F$ count value is greater than F table and significance is less than 0.05. It means that simultaneously the BPK audit opinion, Audit findings, Audit Results Follow up, Legislative Size, Local Government Size, Local Dependence, Local Expenditures have 
significant effect on Local Financial Performance. This also means that regression model $\mathbf{Y}=\mathbf{0 . 0 7 3 + 0 . 0 9 6 X 1 -}$ $0.007 \times 2+0.241 \times 3+0.005 \times 4+0.002 \times 5-0.205 \times 6+0.0000 \times 7$ is feasible.

The correlation value is 0.686 . It shows the magnitude of BPK audit opinion, Audit findings, Audit Results Follow up, Legislative Size, Local Government Size, Local Dependence, and Local Expenditures. The squared will produce an R square value of 0.470 or $47 \%$. These results indicate that BPK audit opinion, Audit findings, Audit Results Follow up, Legislative Size, Local Government Size, Local Dependence, Local Expenditures affect Local Financial Performance by $47 \%$, while the other $53 \%$ are affected by other variables outside of researched variables. The next step is hypothesis testing.

\section{Hypothesis Testing and Discussion}

Table 1 shows that BPK audit opinion variable has $t$ value of 2.157 and a significance of $0.033<0.05$. It means BPK audit opinion partially has significant effect on Financial Performance. Regression coefficient value 0.096 showed the positive effect. It means that financial performance will increase by 0.096 units for every one-unit increase of BPK audit opinion. These results indicate that hypothesis H1 is accepted.

This research results are consistent with Endri Parwanto (2017) that audit opinion and timeliness of financial statement submission have a significant effect on local government financial performance. Previous studies also revealed that audit opinion affect on the financial performance (Parwanto \& Harto, 2017) as well as (Nur Ade Noviyanti, 2017). However, other research found that audit opinion did not affect on local financial performances. Local governments have not paid much attention to results of audit opinions to improve the financial performance of their local governments (Darmawan, 2019).

The Audit Findings variable has a t value of -1.980 and a significance of $0.049<0.05$. It means partially Audit Findings variable has significant effect on Financial Performance. The regression coefficient value -0.007 indicates a negative effect, it means that higher the value of Audit Findings will decrease the Financial Performance. This value can also mean that Financial Performance will decrease by 0.007 units for every oneunit increase from Audit Findings. These results indicate that hypothesis $\mathrm{H} 2$ is accepted.

These results are consistent with Mustikarini and Fitriasasi (2012) that audit findings has a negative effect on performance of district /municipal governments in Indonesia using 2007 data. Similar results were also produced by Sudarsana (2013) using 2010 data. This shows that more findings made by local government, the worse the local government performance. Adversely, Noviyanti \& Kiswoyo (2016) found that measurement of legislature has a negative and significant effect on local government performance finances. Local government size, level of local wealth, audit findings has no effect on local financial performance.

The TLHP variable has a t-count value of 2.379 and a significance of $0.019<0.05$. It shows that TLHP variable partially has significant effect on Financial Performance. The regression coefficient value of 0.241 indicates a positive effect, it means that higher the TLHP value will increase the financial performance. This value can also mean that Financial Performance will increase by 0.241 units for every one-unit increase in TLHP. These results indicate that hypothesis $\mathrm{H} 3$ is accepted.

This research is consistent with Pratiwi and Ayani (2016) who found that follow-up to results of examination had effect on Financial Performance. Sari et al (2015) and Agusti (2014) found that follow-up on audit results had a positive effect on Financial Performance. Sari et al (2015) stated that more follow-up examinations will improve the financial management of local government.

The Local Government Size variable has a t-count value of 2.706 and a significance of $0.008<0.05$. It means that of Local Government Size variable partially has a significant effect on Financial Performance. The coefficient 0.005 indicates a positive effect, meaning that higher the local government size will increase financial performance. This value can also mean that Financial Performance will increase by 0.005 units for every oneunit increase in Local Government Measurement. These results indicate that hypothesis H4 is accepted.

This findings are consistent with Lin et al., (2010) and Kusumawardani (2012) that local government size as measured by total assets has an effect on local government performance. In addition, Siti Juweny (2016) showed that region size and level of local wealth have a significant positive effect on performance of provincial governments in Indonesia.

Legislative Size Variable has a $\mathrm{t}$ value of 2.138 and a significance of 0.034 so $<0.05$. It means that Legislative Size variable partially has significant effect on Financial Performance. The regression coefficient value of 0.002 indicates a positive effect. It means that higher the value of Legislative Size will improve the Financial Performance. This value can also mean that Financial Performance will increase by 0.002 units for every one-unit increase in Legislative Measures. These results indicate that hypothesis H5 is accepted.

These results are consistent with Masdiantini \& Erawati (2016) that local government size and BPK audit opinion has a significant positive effect on financial performance. In addition, Hendro Sumarjo (2010), found that local government characteristics affect on finances performance of local government. The financial performances of local government affected by the size of local government.

Local Dependence has $t$ value of -2573 and significance of $0011<0.05$. It means that Local dependence has 
significant effect on Financial Performance. The regression coefficient value of -0.205 indicates a negative effect. It means that higher the value of Local Dependence will decrease the Financial Performance. This value can also mean that Financial Performance will decrease by 0.205 units for every one-unit increase in Local Dependence. These results indicate that hypothesis H6 is accepted.

The results of this research are consistent with Julitawati et al (2012) that matching grant had a negative effect on financial performance of District/City Government. Fontanella and Rossieta (2014) also found that dependence on Central Government has a negative effect on financial reporting accountability. In addition, Wahyu Ningsih (2016) also found that matching grant have a negative effect on financial performance of local government in Central Java Province.

The Local Expenditure variable has a t-count value of 4.640 and a significance of $0.000<0.05$. It means that Local Expenditure partially has a significant effect on Financial Performance. The regression coefficient value of 0.000 indicates a positive effect, meaning that higher the value of Local Expenditures will improve the Financial Performance increase. This value can also mean that Financial Performance will increase by 0.000 units for every one-unit increase in Local Expenditures. These results indicate that hypothesis $\mathrm{H} 7$ is accepted.

These results are not consistent with Mustikarini and Fitriasasi (2012) that examining the effect of Local size, wealth level, dependency level, local expenditure and BPK audit findings on performance. All variables have a significant effect on independent variables in a direction that consistent with hypothesis except for local expenditure variable

\section{CONCLUSIONS AND SUGGESTIONS}

Based on the research results, the conclusions can stated below.

1. Audit Opinion partially has a significant effect on Financial Performance.

2. Audit Findings partially has a significant effect on Financial Performance.

3. TLHP partially has a significant effect on Financial Performance.

4. Local Government Size partially has a significant effect on Financial Performance.

5. Legislative Size partially has a significant effect on Financial Performance.

6. Local Dependence partially has a significant effect on Financial Performance.

7. Local Expenditure partially has a significant effect on Financial Performance.

Based on the research results, suggestions can be stated below.

1. Future researchers should analyze other factors that having effect on financial performance.

2. Future researchers should develop this research by more complex statistical analysis with adding research samples at a wider level.

3. Future researchers should add other dependent variables that can affect financial performance to produce a better effect than the previous results.

\section{REFERENCES}

Agusti, Yola, dan Wirna. (2014). Pengaruh provitabilitas leverage, corporate governance terhadap tax avoidance. Jurnal Akuntansi : Volume. 2 No. 3

Arifianti, H. (2013). Pengaruh Pemeriksaan dan Pengawasan Keuangan Daerah terhadap Kinerja Penyelenggaraan Pemerintahan Daerah (Studi Empiris pada Pemerintah Kabupaten/Kota di Indonesia) (Doctoral dissertation, UNS (Sebelas Maret University)).

Darmawan, D. (2019). Pengaruh Karakteristik Pemerintah Daerah Dan Hasil Pemeriksaan BPK Terhadap Kinerja Pemerintah Daerah (Studi Pada Kota/Kabupaten Di Provinsi Jawa Barat Tahun 2010-2014). Journal of Chemical Information and Modeling, 53(9), 1689-1699. https://doi.org/10.1017/ CBO9781107415324.004

Fassa, M. N. (2018). Kinerja Keuangan Pemerintah Daerah (Studi Empiris pada Pemerintah Daerah Kabupaten / Kota di Indonesia ).

Ghozali, Imam. 2013. Aplikasi Analisis Multivariate dengan Program IBM SPSS 21. Edisi 7. Semarang: Badan Penerbit Universitas Diponegoro.

Gita Maiyora. (2016). Pengaruh Karakteristik Pemerintah Daerah Terhadap Kinerja Keuangan Pemerintah Darah Kabupaten/Kota (Studi Empiris Kabupaten/Kota di Pulau Sumatera). JOMFekom, 4(1), 1960-1970.

Halim, A. (2012). Manajemen Keuangan Daerah. Penerbit Andi Yogyakarta.

Madiasmo. (2009). Akuntansi Sektor Publik. Penerbit Andi Yogyakarta.

Mulyadi. (2014). Sistem Akuntansi. In Salemba Empat Jakarta (Cetakan ke). Salemba Empat.

Juweny, S. (2016). Pengaruh Karakteristik Pemerintah Daerah Dan Temuan Audit Bpk Terhadap Kinerja Pemerintah Daerah Provinsi Di Indonesia (Doctoral dissertation, Fakultas Ekonomi Dan Bisnis).

Mustikarini, Widya Astuti, Dan Fitriasari, D. (2012). Pengaruh Karakteristik Pemerintah Daerah dan temuan Audit BPK terhadap Kinerja Pemerintah Daerah kabupaten/kota di Indonesia tahun anggaran 2007. Simposium Nasional Akuntansi, 15. 
Nandhya Marfiana, L. K. (2018). Pengaruh Karakteristik Pemerintah Daerah dan Hasil Pemeriksaan Audit BPK Terhadap Kinerja Keuangan. Bongaya Journal for Research in Accounting (BJRA), 1(2), 51-55. https://doi.org/10.37888/bjra. v1i2.86

Nur Ade Noviyanti, K. (2017). Pengaruh Karakteristik Pemerintah Daerah, Temuan Audit BPK Terhadap Kinerja Keuangan Pemerintah Daerah. Accounting Analysis Journal, 12(3), 234-247.

Parwanto, E., \& Harto, P. (2017). Pengaruh Hasil Pemeriksaan BPK Terhadap Kinerja Keuangan Pemerintah Daerah. Diponegoro Journal of Accounting, 6(1), 35-43.

Pratiwi, R dan Aryani, A, Y. (2016). Pengaruh karakteristik pemerintah daerah, kepala daerah, tindak lanjut temuan audit terhadap opini audit. Jurnal Akuntansi : Volume. XX, No. 02, hal 167-189.

Rini, A., \& Hepi Prayudiawan, S. E. (2016). Pengaruh Opini Audit, Fungsi Pengawasan Dprd, dan Karakteristik Pemerintah Daerah Terhadap Kinerja Keuangan Pemerintah Daerah (Bachelor's thesis, Jakarta: Fakultas Ekonomi dan Bisnis UIN Syarif Hidayatullah Jakarta).

Sari, P, A, Martini, D, dan Setyaningrum, D. (2015). Pengaruh temuan audit, tindak lanjut hasil pemeriksaan dan kualitas sumber daya manusia terhadap opini audit melalui tingkat pengungkapan laporan keuangan kementerian/lembaga. Jakarta : Universitas Indonesia.

Sekaran. (2011). Research Methods for Business. In Salemba Empat Jakarta (Edisi 1 da). Salemba Empat Jakarta . (2016). Martin Tuchman School of Management BS in Business Learning Objectives. Salemba Empat Jakarta.

Sudarsana, H. S., \& Rahardjo, S. N. (2013). Pengaruh Karakteristik Pemerintah Daerah Dan Temuan Audit Bpk Terhadap Kinerja Pemerintah Daerah. Diponegoro Journal of Accounting, 2(6), 1-13.

Sumarjo, H. (2010). Pengaruh karakteristik pemerintah daerah terhadap kinerja keuangan pemerintah daerah.

Taher. (2018). KPK beberkan modus korupsi 32 kepala daerah yang terjaring OTT. Tirto.id. 